\title{
Kupffer Cells Influence Parenchymal Invasion and Phenotypic Orientation, but Not the Proliferation, of Liver Progenitor Cells in a Murine Model of Liver
} Injury

Noémi Van Hul, ${ }^{*}$ Nicolas Lanthier, ${ }^{*}$ Regina Español Suñer, ${ }^{*}$ Jorge Abarca Quinones, ${ }^{*}$ Nico van Rooijen, ${ }^{\dagger}$ and Isabelle Leclercq ${ }^{*}$

From the Laboratory of Hepato-Gastroenterology,* Institut de Recherche Expérimentale et Clinique, Université catholique de Louvain (UCL), Brussels, Belgium; and the Department of Molecular Cell Biology, ${ }^{\dagger}$ Vrije Universiteit Medical Center, Amsterdam, the Netherlands

Activation of myofibroblasts (MF) and extracellular matrix (ECM) deposition predispose the expansion and differentiation of liver progenitor cells (LPC) during chronic liver injury. Because Kupffer cells (KC) are active modulators of tissue response and fibrosis, we analyzed their role in a model of LPC proliferation. A choline-deficient diet, supplemented by ethionine (CDE) was administrated to $\mathrm{C} 57 \mathrm{B1} / 6 \mathrm{~J}$ mice that were depleted of $\mathrm{KC}$ by repeated injections of clodronate (CLO) and compared to PBS-injected mice. On CDE, massive $\mathrm{KC}$ activation was observed in the PBS group, but this was blunted in CLO-treated mice. The depletion of KC did not influence LPC proliferation but reduced their invasive behavior. Instead of being found far into the parenchyma, as was found in the PBS group (mean distance from portal vein: $209 \mu \mathrm{m}$ ), LPC of CLO mice remained closer to the portal area $(138 \mu \mathrm{m})$, forming aggregates and phenotypically resembling cells of biliary lineage. Notably, removal of $\mathrm{KC}$ was also associated with a significant decrease in amount of MF and ECM and in the expression of profibrotic factors. Thus, besides ECM and MF, KC are also a significant component of the microenvironmental changes preceding LPC expansion. Depletion of KC may limit the LPC parenchymal invasion through a deficiency in chemoattracting factors, reduced activation of MF, and/or a paucity of the ECM framework necessary for cell motility. (Am J Pathol 2011, 179:1839-1850; DOI: 10.1016/j.ajpath.2011.06.042)
Rapidly after liver damage, unharmed hepatocytes undergo proliferation to make up for the suffered cell loss, and regain normal function. However, in case of massive and/or chronic injury, this process is insufficient as a result of either a paucity of hepatocytes able to engage in the regenerative process or replicative inability of the remaining hepatocytes. In those conditions, recapitulated in the CDE mouse model used here, ${ }^{1}$ a dormant compartment of progenitor cells is activated and considered as a rescue mechanism for functional liver mass regeneration. Liver progenitor cells (LPC) are described as bipotential, being able to differentiate into biliary or hepatocytic lineages, depending on the injurious processes. $^{2}$

The canals of Hering are home to the adult progenitor cell niche ${ }^{3}$ and represent a physiologically limited microenvironment, providing anchor and shelter in a growth- and differentiation-restricted environment for LPC maintenance, by sequestering them from differentiation or apoptotic stimuli. ${ }^{4}$ Structurally, the niche is predicted to enclose various cell populations surrounding and supporting the LPC in unique topological relationships, as well as secreted factors emanating from cells located both in- and outside of the niche. Those features would make it possible for the niche to sense and to react

Supported by the Belgian State-Belgian Federal Science Policy Office (BELSPO) as part of the "Interuniversity Attraction Poles" (IAP) program (network P6/36) and by the Institute for the encouragement of Scientific Research and Innovation of Brussels (IRSIB) as part of the BRUSTEM project. I.L. is research associate with the "Fonds National de la Recherche scientifique" (FNRS).

Accepted for publication June 27, 2011.

N.V.H. and N.L. contributed equally to this work.

Supplemental material for this article can be found at http://ajp. amjpathol.org or at doi: 10.1016/j.ajpath.2011.06.042.

Address reprint requests to Isabelle Leclercq, M.D., Ph.D., Laboratoire de Gastroentérologie, Université catholique de Louvain, GAEN53/79, Avenue Mounier, 53, B-1200 Brussels, Belgium. E-mail: isabelle.leclercq@ uclouvain.be. 
to external changes and to activate and mobilize LPC whenever mature cell lineages are needed. ${ }^{5,6}$

The exact cellular composition and associated molecular signals of the LPC niche remain elusive. It is known, however, that together with the LPC-mediated regeneration, both inflammatory and fibrotic responses take place. $^{7}$ In a previous study, we have shown that by exposing C57BI/6J mice to a choline-deficient diet supplemented in ethionine (CDE), a strong proliferative response of LPC was induced, associated with a colocated and equally important deposition of extracellular matrix (ECM) by myofibroblasts (MF). ${ }^{8}$ Direct cell-cell communication between LPC and MF has been shown to involve interactions of lymphotoxin $\beta$ (LT $\beta)$ and regulated on activation normal T cell expressed and secreted (RANTES) with their receptors, LT $\beta R$ and CCR5, respectively. ${ }^{9}$ The importance of MF/ECM deposition has recently been highlighted in the acetylaminofuorene/partial heptectomy rat model, where L-cysteine treatment that inhibited hepatic stellate cell (HSC) population resulted in a blunted oval cell response, ${ }^{10}$ plausibly because of a combination of the loss of a major source of cytokines with the failure to provide appropriate ECM. Although ECM production by MF seems, not only to form the supportive component of the niche, but also to be implicated in the creation of a specific LPC microenvironment, the role of the accompanying (noninfectious) inflammatory response is less clear. Immunodeficient and alymphoid mouse models have been used to demonstrate that, in contrast to B and NKT cells, both T lymphocytes and NK cells are essential for the proliferation of CDE-induced LPC by local secretion of mitogenic/stimulating cytokines such as tumor necrosis factor- $\alpha(\mathrm{TNF} \alpha)$ and interferon- $\gamma(\mathrm{IFN} \gamma) .{ }^{11}$ Even more, the polarization of the host innate immune response is also involved, with a blunted LPC reaction in animals with Th2-polarized immune response compared to predominantly Th1-responding animals. ${ }^{12}$ This suggests that LPC proliferation following chronic injury may be dependent on cell-cell contact and/or secreted cytokines from resident and infiltrating immune cells in the CDE model. Better identification and characterization of specific components of the immune system participating to the LPC response are therefore required.

Kupffer cells (KC) are resident hepatic macrophages playing important roles, not only in the phagocytosis of cell debris, but also in liver physiology, by secretion of inflammatory factors in response to stimulation or toxic compounds. Their role is ambiguous because they are considered to be both protectors from and promoters of liver injury in various conditions. ${ }^{13,14}$ In addition, their participation in both liver fibrosis progression (by generating reactive oxygen species, proinflammatory factors, and profibrotic factors) and regression (by degrading ECM, exerting anti-inflammatory action, and eliminating activated matrix-producing cells) has been well established. ${ }^{13,15,16}$ The aim of this study was to elucidate another role of $\mathrm{KC}$, namely on the activation, proliferation, and/or parenchymal invasion of LPC by exposing mice to a CDE diet with or without $\mathrm{KC}$ depletion obtained by injections of clodronate-loaded liposomes.

\section{Materials and Methods}

\section{Animals, Diets, and Treatment}

Five-week-old male C57BI/6J mice obtained from Janvier-Breeding Center (Le Genest St Isle, France) were housed under pathogen-free conditions. The animals were handled according to guidelines for humane care for laboratory animals established by the Université catholique de Louvain in accordance with European Union regulation, and the study protocol was approved by the local ethics committee. Mice were randomly assigned to one experimental group and received normal chow or a diet deficient in choline (MP Biomedicals, Irvine, CA) supplemented with $0.15 \%$ (w/v) ethionine (Sigma, Bornem, Belgium) (CDE diet). ${ }^{8}$ Food and water were provided ad libitum. Mice were sacrificed at 3, 7, or 10 days after initiation of the diet. Analyses were performed on a minimum of five animals per group/time point. After euthanasia, the liver was rapidly excised. Part of the liver was fixed in $4 \%$ formalin or immediately snap frozen in liquid nitrogen and kept at $-80^{\circ} \mathrm{C}$ until use.

To deplete macrophages, $150 \mu \mathrm{L}$, per 20 grams of body weight, of $1 \mathrm{mg} / \mathrm{mL}$ liposome-encapsulated clodronate were injected into mice by the intravenous route via the retro-orbital plexus, 24 hours before administration of the CDE diet (CLO group). In a second experiment, injections were repeated every 3 days. Analogously, controls received injections of liposome-encapsulated PBS (PBS group) (see Supplemental Figure S1 at http:// ajp.amjpathol.org). An equal volume of $\mathrm{NaCl} 0.9 \%$ was injected intravenously into mice fed a normal chow (CTL group). Clodronate (a gift from Roche Diagnostics $\mathrm{GmbH}$, Mannheim, Germany) was encapsulated into liposomes as described previously. ${ }^{17}$

\section{Histology and Immunohistochemistry}

Hematoxylin-eosin and Sirius Red stainings were performed using standard protocols. For immunohistochemical detections, 5- $\mu \mathrm{m}$ liver sections were deparaffinized and rehydrated in baths of graded alcohol. Endogenous peroxidase was blocked by immersion in $3 \% \mathrm{H}_{2} \mathrm{O}_{2}$ in methanol for 15 minutes. For antigen retrieval, slides were submitted to either heat-induced epitope retrieval in citrate buffer ( $\mathrm{pH} 8.0$ ) for 45 minutes at $100^{\circ} \mathrm{C}$ or proteinase $\mathrm{K}$ digestion for 20 minutes at $37^{\circ} \mathrm{C}$. After BSA $1 \%$ for 30 minutes (room temperature), sections were incubated for 1 hour at $37^{\circ} \mathrm{C}$ with specific primary antibodies directed against cytokeratin 19 (CK19, 1:50; Developmental Studies Hybridoma Bank, lowa City, IA), $\alpha$-smooth muscle actin ( $\alpha$-SMA, 1:50; Dako, Glostrup, Denmark), E-cadherin (1:500; BD Biosciences, San Jose, CA), occludin (1:200; Abcam, Cambridge, UK), $\beta$-catenin (1:50; BD Biosciences), Ki-67 (1:200; Abcam), or F4/80 (1:200; Serotec, Oxford, UK). Detection was performed using antirat peroxidase-coupled secondary antibody (1:200; Dako) or anti-rabbit or anti-mouse Envision (Dako). Peroxidase activity was revealed by diaminobenzidine (Dako). Slides were counterstained with hematoxylin. For fluorescence, secondary anti-rat Alexa fluor 488 and anti- 
Table 1. Primer Sequences for Real-Time PCR Analyses of Gene Expression

\begin{tabular}{|c|c|c|}
\hline \multicolumn{3}{|c|}{ Primer sequences } \\
\hline Gene & Forward & Reverse \\
\hline$\alpha-S M A$ & 5'-TCCTGACGCTGAAGTATCCGATA-3' & 5'-GGTGCCAGATCTTTTCCATGTC-3' \\
\hline CD133 & 5'-GGAAAGCCACGGTGCTCTT-3' & 5'-ACTTGGCCAGCTTGATAGCAA-3' \\
\hline CK19 & $5^{\prime}$-AGCGTGATCAGCGGTTTTG-3' & 5'-CCTGGTTCTGGCGCTCTATG-3' \\
\hline Collagen I & 5' -GACTGGAAGAGCGGAGAGTACTG-3' & 5'-CAGGTCTGACCTGTCTCCATGTT-3' \\
\hline E-cadherin & $5^{\prime}$ - CTTTTCGGAAGACTCCCGATT-3' & 5'-GCTTTAGATGCCGCTTCACTGT-3' \\
\hline F4/80 & 5'-GATGAATTCCCGTGTTGTTGGT-3' & $5^{\prime}$-ACATCAGTGTTCCAGGAGACACA-3' \\
\hline HGF & $5^{\prime}$-TCGTGGCAATGGGAAAAATT-3' & 5' -GGAACATGTAAGTCCAGACCTTGTT-3' \\
\hline ICAM1 & $5^{\prime}$-CCGCAGGTCCAAT TCACACT-3' & $5^{\prime}-$ CAGAGCGGCAGAGCAAAAG- $3^{\prime}$ \\
\hline$I F N \gamma$ & 5'-TTGGCTTTGCAGCTCTTCCT-3' & $5^{\prime}-$ TGACTGTGCCGTGGCAGTA-3' \\
\hline 124 & 5'-GGAGATGGATGTGCCAAACG-3' & 5'-CGAGCTCACTCTCTGTGGTGTT-3' \\
\hline IL10 & $5^{\prime}-$ GATGCCCCAGGCAGAGAA- $3^{\prime}$ & $5^{\prime}-$ CACCCAGGGAATTCAAATGC- $3^{\prime}$ \\
\hline$L T \beta$ & $5^{\prime}$-GGAGCACAGGCTCAGAAAAGA-3' & $5^{\prime}$-GGGTGAGGGCAAGATGCA-3' \\
\hline NKG2D & $5^{\prime}$-GGCAATTCGATTCACCCTTAAC-3' & 5' -ATACTGGCTGAAACGTCTCTTTGA-3' \\
\hline RANTES & 5'-TCCAATCTTGCAGTCGTGTTTG-3' & $5^{\prime}-$ TCTGGGTTGGCACACACTTG-3' \\
\hline RPL 19 & 5'-GAAGGTCAAAGGGAATGTGTTCA-3' & 5'-CCTTGTCTGCCTTCAGCTTGT-3' \\
\hline$T G F \beta 1$ & 5'-GCAGTGGCTGAACCAAGGA-3' & $5^{\prime}$-AGCAGTGAGCGCTGAATCG-3' \\
\hline$T N F \alpha$ & 5' -CCACCACGCTCTTCTGTCTAC-3' & $5^{\prime}$-AGTGACAAGCCTGTAGCCCA-3' \\
\hline TWEAK & $5^{\prime}$-GGTGTGGATGGGACAGTGAGT-3' & $5^{\prime}$-GCAGAGGGCTGGAGCTGTT-3' \\
\hline
\end{tabular}

rabbit Alexa fluor 594 were used (1:1000; Invitrogen, Merelbeke, Belgium).

\section{Morphometric, Densitometric, and Invasion Distance Quantification}

Sirius Red, CK19, and $\alpha$-SMA stainings were performed on serial sections. For each liver, 10 microphotographs were randomly taken at $\times 100$ magnification and digitalized through an Axiocam camera (Carl Zeiss, Munich, Germany). The percentage of stained area for each image was averaged to give a mean score per liver as previously described. ${ }^{8}$ Importantly, $\mathrm{CK} 19^{+}$bile ducts (identified by morphology, location, and staining intensity) were not taken into account during the quantification of the CK $19^{+}$LPC. Parenchymal invasion of CK $19^{+}$cells was calculated by measuring the radial distance (in micrometers) from the center of the portal vein to individual $\mathrm{CK} 19^{+}$cells in all directions. Selection of at least five portal veins per liver was based on comparable size and perfect transversal cut. $\beta$-catenin staining intensity was measured by densitometric analysis of the gray unit of positive LPC on microphotographs of 10 portal areas per liver at $\times 400$ magnification. To assess the proliferation rate, cell counts of Ki-67/CK 19 double-positive LPC versus total number of CK19-positive LPC in the same field of view were performed on five portal areas per liver at $\times 400$ magnification (see Supplemental Figure S2 at http://ajp.amjpathol.org). All analyses were performed using Axiovision image analysis software 4.7 (Zeiss).

\section{RNA Extraction, Reverse Transcription, and Quantitative Real-Time PCR}

Real-time PCR analysis of cDNA, synthesized from $1 \mu \mathrm{g}$ of extracted total RNA, was performed as previously described. ${ }^{18}$ Primer pairs for F4/80, CK19, $\alpha$-SMA, transforming growth factor- $\beta 1$ (TGF $\beta 1$ ), collagen I, hepatocyte growth factor (HGF), intercellular adhesion molecule 1 (ICAM1), RANTES, CD133, E-cadherin, IFN $\gamma$, IL4, IL10, $\mathrm{TNF} \alpha$, TNF-like weak inducer of apoptosis (TWEAK), NKG2D, and ribosomal protein L19 (RPL19) were designed using Primer Express design software (Applied Biosystems, Lennik, Belgium) and listed in Table 1. RPL19 mRNA was chosen as an invariant standard. Results are expressed as fold expression relative to expression in the control group (value set at 1) using the $\Delta \Delta \mathrm{Ct}$ method. ${ }^{19}$

\section{Statistical Analysis}

All data are presented as means \pm SD. Differences between groups were analyzed using the unpaired twotailed Student's $t$-test. Statistical significance was assumed for $P<0.05$.

\section{Results}

\section{LPC, HSC, and KC Expansion after CDE Diet}

As previously described, CDE administration leads to expansion of LPC, which is preceded by and associated with an increasing amount of $\alpha-\mathrm{SMA}^{+} \mathrm{MF}$, and ECM, found intermingled with LPC and deposited in front of them along the portocentral axis of migration. ${ }^{8}$ Annexed to this, an extensive infiltration of macrophages was observed in CDE-treated livers compared to control livers (Figure 1). In the control situation, $\mathrm{F} 4 / 80^{+}$cells (KC) are sinusoidal cells with small nuclei and elongated cytoplasm. They are found free-standing and scattered with a preferential location in periportal and midlobular regions, sparing the area around the centrilobular veins (Figure 2A). After 3 days of CDE diet, before the onset of LPC proliferation, activation of the $\mathrm{KC}$ was seen. Phenotypical changes were observed such as rounder and enlarged cells immunostained a darker shade of brown compared to the $\mathrm{KC}$ of control livers. Accumulating cells, isolated or grouped in small strings or aggregates, were found to 
CTL
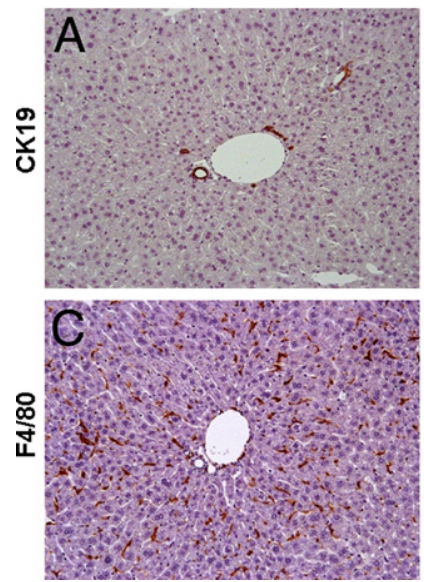

CDE
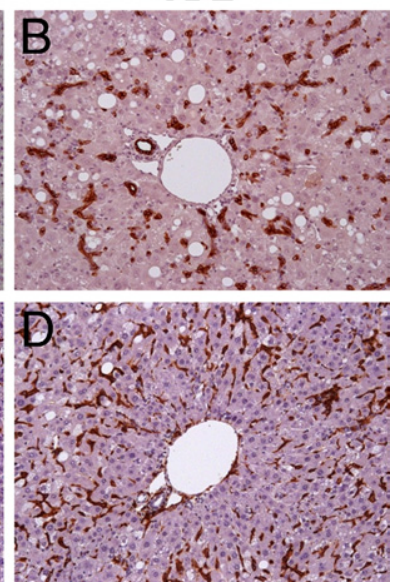

Figure 1. CDE diet induces a strong proliferation of liver progenitor cells and activation of Kupffer cells. Liver sections obtained from control mice (A and $\mathbf{C}$ ) and mice receiving the CDE diet for 21 days (B and $\mathbf{D})$ were stained with antibodies specifically directed against cytokeratin 19 (CK19) (A and B), or F4/80 (C and D) to identify liver progenitor cells and Kupffer cells, respectively. All figures are centered on a portal tract. Original magnification, $\times 200$.

intrude on the area around bile ducts, hotspots of the response to the CDE diet (Figure 2B). After 7 days of $\mathrm{CDE}$ diet, almost all $\mathrm{F} 4 / 80^{+}$cells were arranged in foci, which were larger in size, higher in number, and found farther away from the portal area compared to the 3-day time point (Figure 2C). At that time, LPC started to proliferate, and some cells were seen at a distance from the periportal area (Figure 2G). Later, at day $10, \mathrm{~F} 4 / 80^{+}$cells formed networks where the individual aggregates seen at day 7 (inter)connected into a web (Figure 2D). KC were then more concentrated around the centrilobular veins, resulting in gradually shifting from a preferential periportal/midlobular (day 3) through midlobular/centrilobular (day 7) to centrilobular location (day 10) during CDE treatment, as if KC were clearing in front of LPC, which form strings of cells elongating toward the centrilobular areas (Figure $2 \mathrm{H}$ ).

\section{Consequences of KC Depletion on LPC Proliferation}

To study the influence of the activation of liver macrophages on the LPC reaction, livers were depleted of $\mathrm{KC}$ by intravenous injections of liposome clodronate. ${ }^{20-22}$ In a first experiment, KC were depleted 1 day before CDE administration by a single injection of clodronate (CLO group) and compared to one injection of PBS (PBS group) (see Supplemental Figure S1A at http://ajp. amjpathol.org). Livers were examined after 3 and 7 days of CDE treatment. An almost complete depletion of $\mathrm{KC}$ was shown in the CLO group by a lack of F4/80 mRNA expression at day 3 of the CDE diet (Figure 3A). Extinction of $\mathrm{KC}$ was associated with a significant decrease in $\mathrm{mRNA}$ expression of TGF $\beta 1$, an important profibrogenic factor mainly produced by KC and HSC, and of collagen I mRNA (lowered by one third) compared to the PBS group (Figure 3 , B and C), but not of $\alpha$-SMA mRNA (Figure 3E). At this early time point, LPC activation was absent, such that the number of CK19+ ${ }^{+}$LPC and the CK19 mRNA level in PBS- or CLO-treated CDE livers were not different from controls (Figure 3D). Unfortunately, at day 7, differences between CLO and PBS groups in liver macrophage content, TGF $\beta 1$, and collagen I expression were no longer observed (Figure $3, A-C)$, suggesting that dampening of the initial profibrogenic burst seen at 3 days was related to the removal of $\mathrm{KC}$, and that the CDE livers are rapidly repopulated by macrophages.
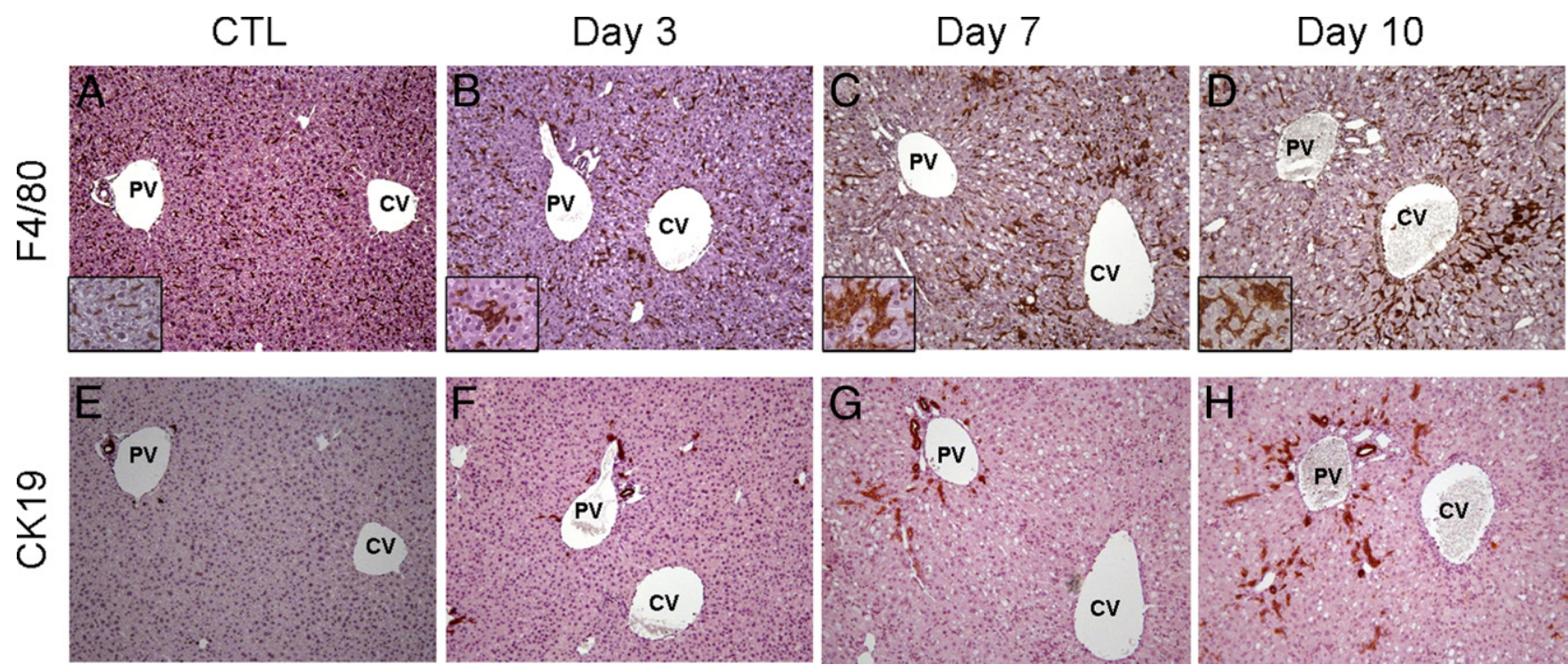

Figure 2. Distribution and phenotype of Kupffer cells in CTL and along the CDE timeline. Liver sections from mice fed a control (A) or a CDE diet for 3 (B), 7 (C), or 10 (D) days stained with F4/80 antibody showing the activation of KC. At day 3, a phenotypical change of single, scattered cells to aggregates and enlarged cells is observed, hereby intruding the periductular zone around the portal vein (pv) (B). At day 7 , the progressive formation of larger foci in midzonal and pericentral areas $(\mathbf{C}$, inset) further concentrated around the central vein $(\mathrm{cv})$ at day 10 (D). Insets show magnification of the KC organization. Original magnification, $\times 400$. CK19 immunostaining in consecutive sections at the similar time points (E-H) document the kinetics of KC topography in relation to expansion of LPC. The pictures display representative photomicrographs. Original magnification, $\times 100$. 

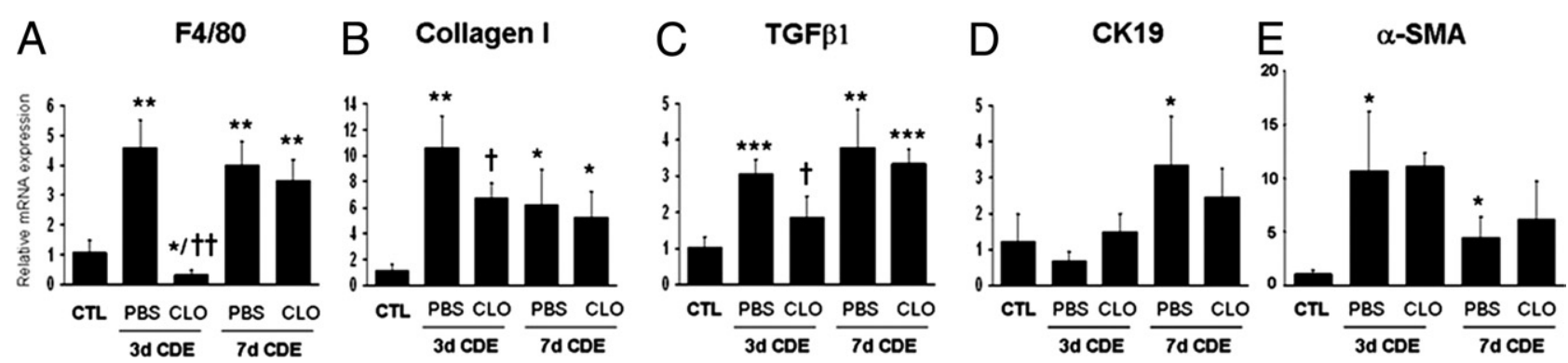

Figure 3. A single injection of clodronate is not sufficient to maintain the effects of Kupffer cell depletion. Effects of a single injection of liposome-encapsulated clodronate (CLO) or PBS in CDE-fed mice on hepatic F4/80 (A), collagen I (B), TGF $\beta 1$ (C), CK19 (D), and $\alpha$-SMA (E) mRNA expression. Liposome injections were performed 24 hours before exposure to CDE diet, and livers were analyzed after 3 or 7 days ( $3 \mathrm{~d}$ and $7 \mathrm{~d}$, respectively). Values were normalized to the expression of RPL19 mRNA, which was regarded as an internal control, and expressed in relation to the mean value in untreated controls, arbitrarily set at 1 . All data are mean ( \pm SD) for $n=5$ /group. ${ }^{*} P<0.05,{ }^{* *} P<0.01$, and ${ }^{* * *} P<0.001$ compared to controls; and ${ }^{\dagger} P<0.05$ and ${ }^{\dagger t} P<0.01$ compared to PBS-treated counterpart at the corresponding time point.

Therefore, in a second set of experiments, clodronateor PBS-loaded liposomes were injected repeatedly at 3-day intervals together with the CDE diet (see Supplemental Figure S1B at http://ajp.amjpathol.org). This proved to be well tolerated (no difference in body weight or behavior was observed between CLO- and PBS-injected CDE animals) and adequate for a maintained removal of KC. Indeed, until day 10 (the end of the experiment), $\mathrm{F} 4 / 80^{+}$cells were absent in clodronate livers (Figure 4E). This was further confirmed by mRNA levels far below those in CTL or PBS livers (Figure 4M). Despite quasi-complete removal of hepatic macrophages, no difference could be seen in the number of $\mathrm{CK} 19^{+}$cells in the CLO group compared to the PBS group at either time point as assessed by immunohistochemistry, morphometric analysis, and mRNA expression (Figure 4B, F, J, and $\mathrm{N}$ ). Estimation of Ki-67 immunostaining in CK19positive LPC confirmed a similar mean cell proliferation rate of PBS $(21.9 \% \pm 0.7 \%)$ and CLO LPC $(20.9 \% \pm$ $1.9 \%$ ) (Figure 4I).

\section{KC Depletion Reduces ECM Deposition}

Confirming previous results, ${ }^{8}$ matrix deposition initiated as early as day 3 of CDE intoxication and expanded with time in both CLO and PBS-treated mice. However, matrix deposition was clearly reduced in CLO-treated livers compared to the PBS counterparts (Figure 4, D and $\mathrm{H}$ ). Contrasting with the dense meshwork of expanding collagen fibers observed at day 10 in the PBS group, rare and thin collagen fibers were seen close to the portal area in CLO CDE livers. These observations were confirmed by morphometric quantification that showed at all time points a significant decrease in Sirius Redstained areas in the CLO group compared to the PBS group (Figure 4L). At day 10, this ECM deficiency in CLO group was even reduced to half of the amount scored for the PBS group. Similarly, collagen I mRNA expression was at all times significantly lower in CLO than in PBS CDE livers with a two-third reduction at 10 days of CDE (Figure 4P).

\section{Effect of Macrophage Depletion on the HSC/MF Population}

Accordingly to previous observations, although there was a strong early up-regulation of $\alpha$-SMA mRNA that later on returned to more modest up-regulated levels, the number of $\alpha$-SMA ${ }^{+}$cells in CDE-exposed animals gradually increased over time. ${ }^{8}$ Although only present in the vascular structure of controls livers, $\alpha$-SMA ${ }^{+}$myofibroblasts from CDE livers gradually spread from the portal area toward the parenchyma in front of the expanding LPC cords that they enclosed. ${ }^{8} \alpha$-SMA staining and mRNA expression were similar at early time points in the PBS and CLO groups, indicating that, in agreement with other reports, ${ }^{23,24}$ clodronate did not directly affect the MF population (data not shown and Figure 3E). In sharp contrast, at day 10 , the number of $\alpha-\mathrm{SMA}^{+}$cells was not only significantly cut back to less than $50 \%$ in the CLO group, but the cells were also located closer to the portal tract (Figure 4, C, G, and K). This was paralleled by a reduced $\alpha$-SMA mRNA expression in the CLO group compared to the PBS group, matching the decreased collagen I production and matrix deposition described above (Figure 40).

\section{KC Depletion Affects LPC's Parenchymal Invasion, Rather Than Activation or Proliferation}

In the PBS group, $\mathrm{CK} 19^{+}$cells progressively spread from the periportal area into the parenchyma (Figure 5, A-C). Contrasting with this invasive phenotype, CK $19^{+}$cells in the CLO CDE livers appeared to remain "motionless" around the portal tracts (Figure 5, D and E). Only very rarely did the cells dissociate from portal aggregates to be found isolated in the lobule. Also, the typical Indian file disposition with head-to-toe alignment of single LPC was difficult to find, and last, elongated cells, a shape supporting tissue invasion, were rarely seen in the CLO group. Rather, LPC of the CLO livers were rounder, with a smaller and more condensed cytoplasm that was strongly positive for CK19 (Figure 5F). They were often found interconnected, forming what appeared as an aggregates stuck to the portal area, in places even delineating a pseudo-lumen (Figure 5E). Similar observations 

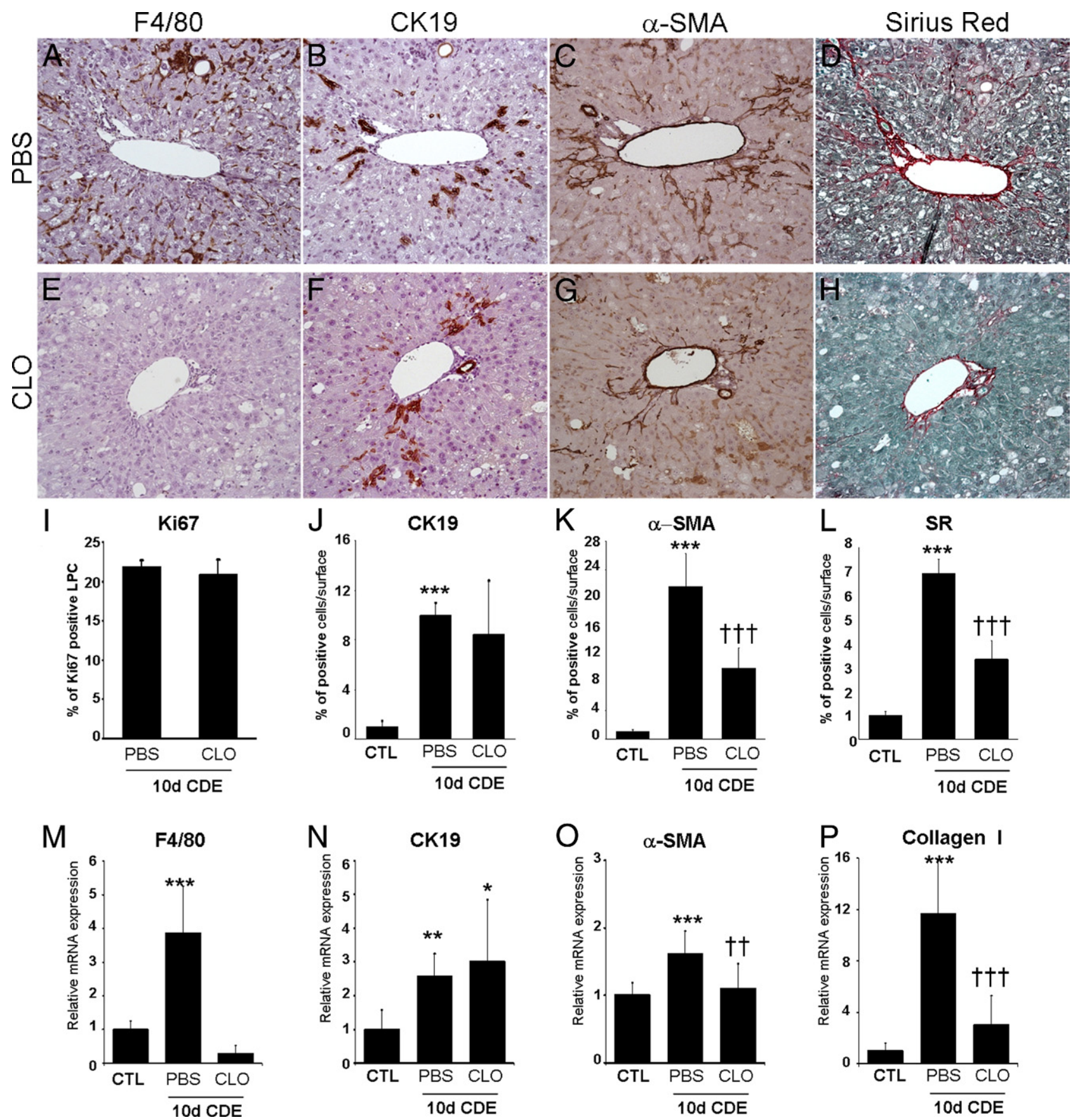

Figure 4. CDE diet and maintained Kupffer cell depletion do not affect progenitor cell population but reduce the amount of myofibroblasts and extracellular matrix. Consecutive liver sections, centered on a portal tract obtained from CDE-fed mice repeatedly treated with PBS-loaded (A-D) or with clodronate-loaded liposomes (CLO; E-H) for 10 days, stained with antibodies specific for F4/80 (A and E), cytokeratin 19 (CK19) (B and F), $\alpha$-smooth muscle actin ( $\alpha$-SMA) (C and G) or with Sirius red $(\mathbf{D}$ and $\mathbf{H})$. Original magnification, $\times 200$. Morphometric quantification of the LPC proliferation rate by Ki-67 immunostaining $(\mathbf{I})$, the area of the liver section occupied by CK19-positive cells (J), $\alpha$-SMA-positive cells (K), or Sirius Red staining (L) in control mice and mice receiving the CDE diet for 10 days (10d) with PBS or CLO treatment. Data are expressed as means ( + SD). Percentage of stained area is related to the total surface of the liver section for $n=5$ /group. Hepatic mRNA expression for F4/80 (M), CK19 (N), $\alpha$-SMA $(\mathbf{O})$, and collagen I (Coll I) (P) in control mice and mice receiving the CDE diet for 10 days with PBS or CLO treatment. Values were normalized to the expression of RPL19 mRNA, regarded as an internal control, and expressed in relation to the mean value in untreated controls, arbitrarily set at 1 . All data are mean $( \pm \mathrm{SD})$ for $n=5$ /group. ${ }^{*} P<0.05,{ }^{* * *} P<0.01$, and ${ }^{* * * * *} P<0.001$ compared to controls; ${ }^{~} P<$ 0.01 and ${ }^{{ }^{H}} P<0.001$ in CLO-treated compared to PBS-treated CDE counterparts.

were made with SOX9, a novel marker of LPC (see Supplemental Figure S3 at $h$ ttp://ajp.amjpathol.org) ${ }^{25}$ To confirm the reduced parenchymal penetration of $L P C$ in CLO, we measured distances between the center of the portal vein and LPC over $360^{\circ}$. Although this distance averaged to $\sim 200 \mu \mathrm{m}$ in the PBS group, it barely reached $150 \mu \mathrm{m}$ in CLO group, representing a significant decrease of $25 \%$ (Figure $6 \mathrm{~A}$ ). Also, a comparison of the maximal distance reached by LPC in individual portal tracts showed that PBS LPC got as far as $325 \mu \mathrm{m}$ away from the portal vein compared to $220 \mu \mathrm{m}$ in the CLO group (Figure $6 \mathrm{~B})$. Together, these results showed, not that only the 

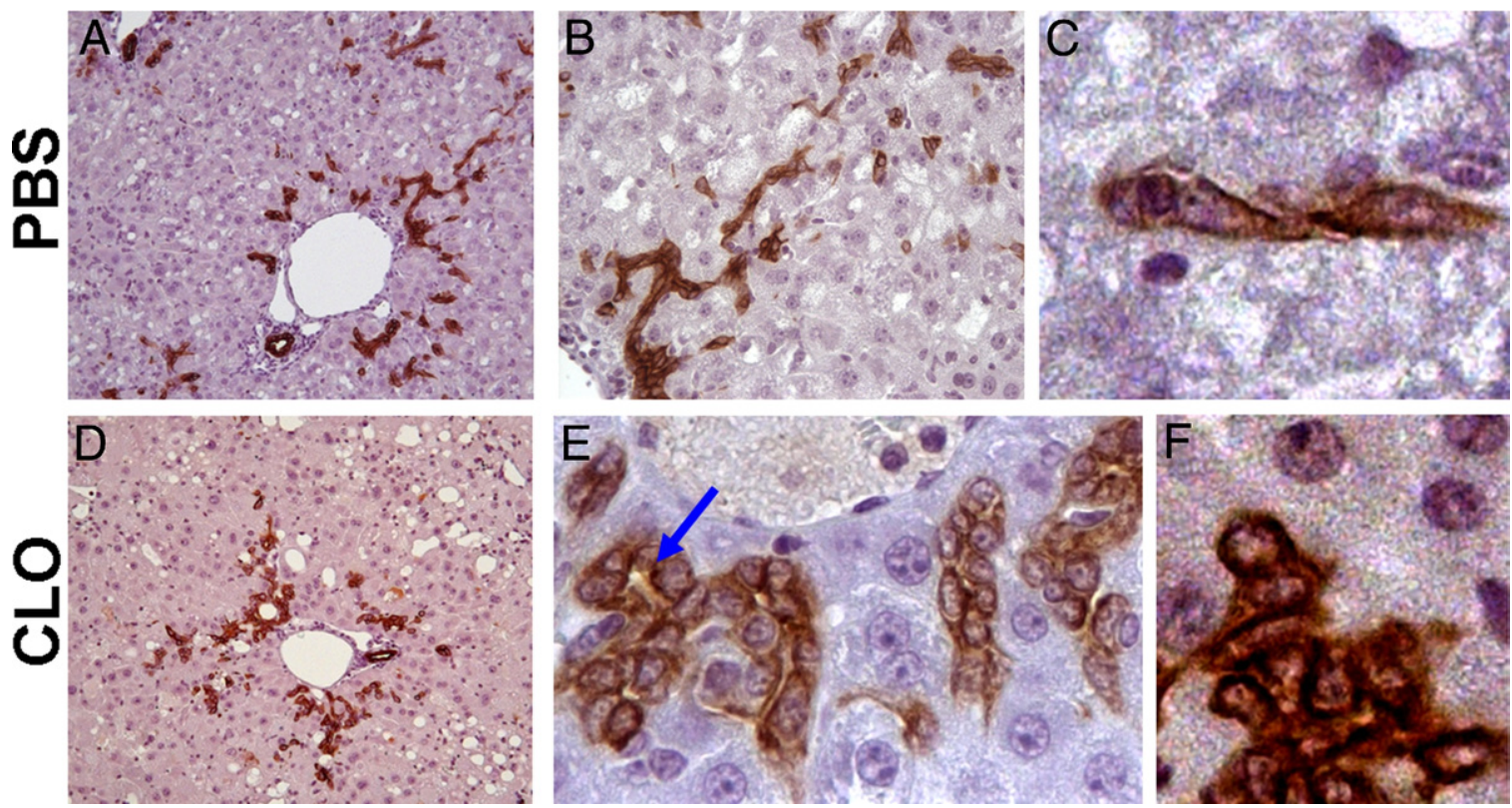

Figure 5. Alteration in morphology of progenitor cells after prolonged Kupffer cell depletion. Liver sections of CDE-fed mice repeatedly treated with PBS (A-C) or with clodronate (CLO) for 10 days (D-F) stained with a CK19 antibody. Original magnification: $\times 100$ (A and D); $\times 200$ (B and E); $\times 400$ (C and F); highlighting the morphological difference in LPC. The elongated PBS LPC (C) are organized in strings or found as single cells (B), compatible with their migration into the parenchyma (A), whereas CLO LPC are located closer to the portal tract (D), form aggregates occasionally defining a pseudo-lumen (E, blue arrow), and have a rounder phenotype $(\mathbf{F})$

majority of LPC in the PBS group were located further away from the portal veins, but also that individual and more evidently invading cells were found deeper in the parenchyma.

To document this apparent reduced invasive capacity after clodronate treatment, we examined several elements implicated in cell-cell or cell-matrix attachment as well as in cell motility. HGF, mainly produced by HSC/ $\mathrm{MF}^{26}$ and formerly known as "scatter factor," ${ }^{27}$ has been demonstrated to induce the generation and maintenance of an invasive phenotype in epithelial cells by promoting proliferation, disruption of cell-cell contacts, and migration through the ECM ("scatter"). ${ }^{28}$ HGF mRNA expression was found to increase significantly under CDE treatment (Figure 7A). On KC depletion, the level of HGF expression did not even reach the level found in control livers. ICAM1 and RANTES, two chemotaxis-related molecules associated with the recruitment of LPC, ${ }^{9}$ were significantly reduced in CLO CDE livers compared to the
PBS group, as shown by quantitative real-time PCR analysis (Figure 7, B and C).

An initial step in acquisition of cell invasiveness is identified as the loss of function of adhesion molecules involved in the maintenance of tissue compaction, including the cadherin-catenin complex. ${ }^{29,30}$ Down-regulation of any of the components of this complex leads to unstable intercellular adhesions facilitating cell migration. ${ }^{31}$ LPC express E-cadherin, ${ }^{32,33}$ but E-cadherin mRNA and protein were not found to be differentially expressed between PBS and CLO groups (Figure $8 \mathrm{C}$ and data not shown). In contrast, although nuclear staining could not be detected in either PBS or CLO CDE liver, staining of membranous $\beta$-catenin, interconnecting adhesion junction protein E-cadherin to the cytoskeleton, was found to be stronger after $\mathrm{KC}$ depletion. Although $\beta$-catenin finely and partially delineated the plasma membrane of PBS LPC, the staining was stronger and denser, outlining the entire cell membrane in CLO LPC, indicating that the
A

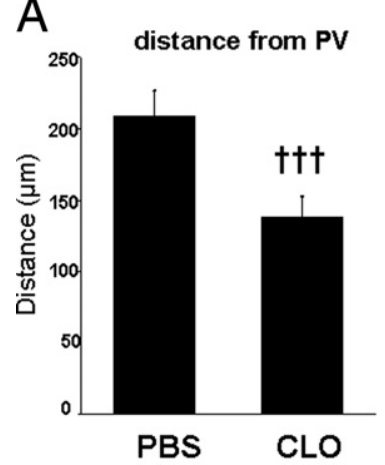

\section{B} maximal distance from PV

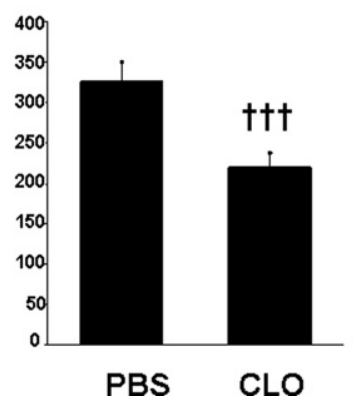

C

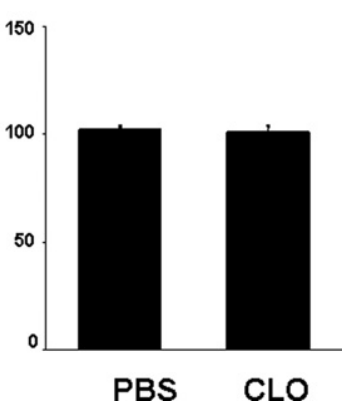

Figure 6. Lower migration distance for clodronate progenitor cells at day 10 . Graphs representing quantitative measurements of LPC spreading from the portal tract in CDE-fed mice repeatedly treated with $\mathrm{PBS}$-loaded or with clodronate-loaded liposomes (CLO): (A) mean distance measured between the center of portal tract and individual LPC, (B) maximal distance from the portal tract reached by the head of migration front of the LPC (mean of five portal tracts per liver), and (C) diameter of the portal vein (PV) of the portal tract analyzed. Measurements were performed as detailed in Materials and Methods. ${ }^{\mathrm{t}} P<0.001$, CLO versus PBS group. 

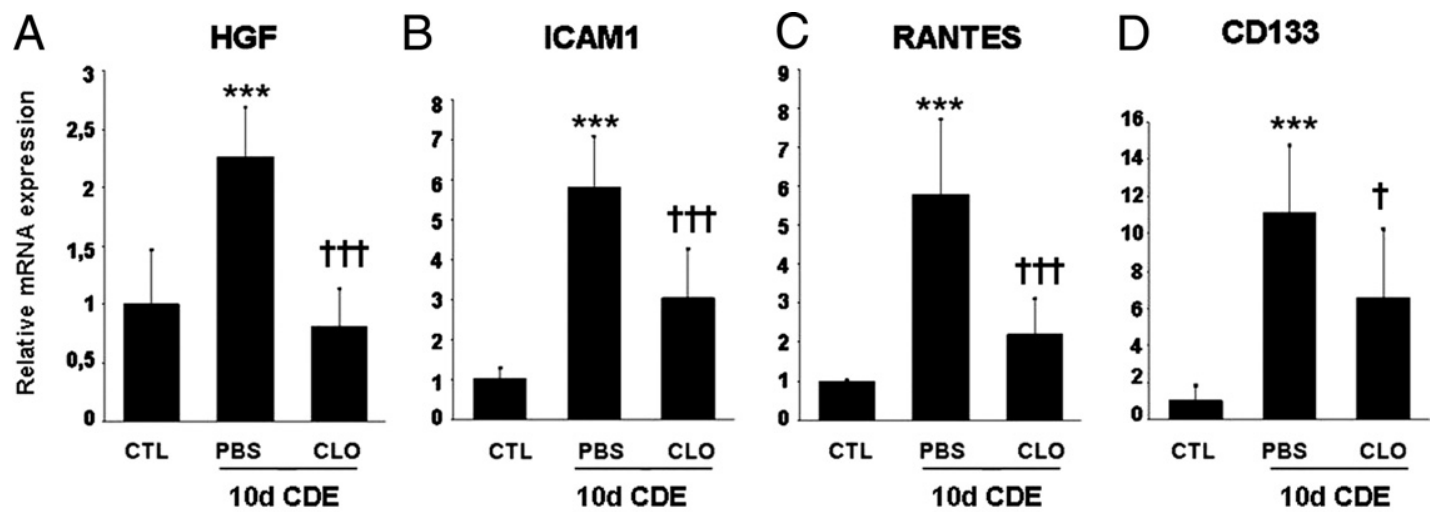

Figure 7. After repeated clodronate treatment, LPC have an apparent reduced invasive character. Hepatic mRNA expression of HGF (A), ICAM1 (B), RANTES (C), and CD133 (D) in control mice and mice receiving the CDE diet for 10 days with repeated PBS or CLO treatment. Values were normalized to the expression of RPL19 mRNA, regarded as an internal, control and expressed in relation to the mean value in untreated controls, arbitrarily set at 1 . All data are mean ( \pm SD) for $n=5$ /group. ${ }^{* * * *} P<0.001$ compared to controls; and ${ }^{\dagger} P<0.05$ and ${ }^{t+\dagger} P<0.001$ in CLO-treated compared to PBS-treated CDE counterparts.

cells were held tighter together (Figure $8, \mathrm{~A}$ and $\mathrm{B}$ ). This observation of a thicker layer of $\beta$-catenin after clodronate was confirmed by densitometric analysis indicating a significant difference between PBS (gray unit of 34.83) and CLO (45.49, with $P<0.001$ ) (Figure 8D).

We also investigated occludin, known to function as an adhesion structure and to be essential for migration. ${ }^{34}$ By immunofluorescence, occludin was distributed over the entire membrane of elongated PBS LPC. In CLO LPC as in biliary cells, occludin was restricted to the basolateral membrane supporting polarity (see Supplemental Figure S4 at http://ajp.amjpathol.org). This data reinforced the previous observations. Interestingly, mRNA expression of
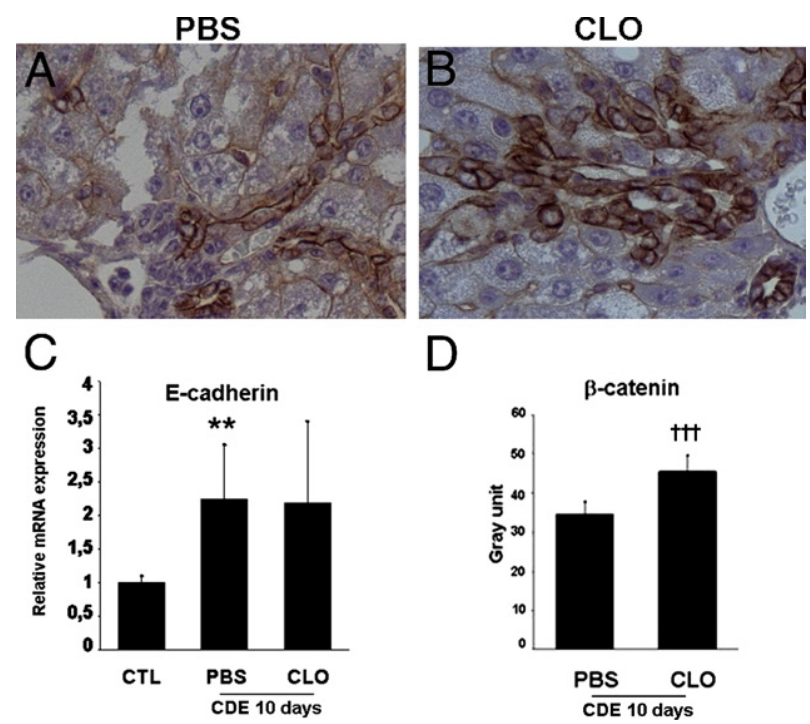

Figure 8. Membranous $\beta$-catenin staining is stronger in progenitor cells of prolonged Kupffer cell-depleted livers. Liver sections of CDE-fed mice repeatedly treated with PBS-loaded (A) or with clodronate-loaded liposomes (CLO; B) for 10 days stained with a $\beta$-catenin antibody. Original magnification: $\times 400$. In the PBS group, $\beta$-catenin finely outlines the plasma membrane of LPC. In the CLO group, staining is denser. Note that LPC in CLO (B) are in places organized in pseudo-ductular structures. Hepatic mRNA expression of E-cadherin $(\mathbf{C})$ in control mice and mice receiving the CDE diet for 10 days with PBS or CLO treatment $\left({ }^{* *} P<0.01\right)$ is shown. Densitometric analysis of $\beta$-catenin staining (D) expressed in mean gray units/surface unit $( \pm S D)$ in $n=5$ livers per group. ${ }^{t+1} P<0.001$ in CLO versus PBS group.
CD133, a marker of immature LPC lost during early differentiation, ${ }^{35}$ was significantly reduced by one-third in CLO livers compared to the PBS group (Figure 7D).

\section{Consequence of KC Depletion on Expression of Cytokines Able to Impact on LPC}

Although not documented here, KC depletion-induced ECM changes are expected to affect recruitment and function of other inflammatory cells in the liver as suggested by decreased expression of the chemokines ICAM1 and RANTES (Figure 7, B and C) and of the NKG2D activator receptor of NK cell (see Supplemental Figure S5 at http://ajp.amjpathol.org). In PBS mice, hepatic TGF $\beta 1$ and TNF- $\alpha$ mRNA expression were increased (Figure 9, A and B), whereas at all time points, the expression of TWEAK, described as a selective mitogen of LPC, did not differ from the control value (Figure 9C). ${ }^{12,36}$ On clodronate, we observed a reduction in mRNA expression of TGF $\beta 1$, TNF- $\alpha$, and TWEAK at all time points compared to the PBS group. IFN $\gamma$ and IL4 expression were equally reduced in the PBS and CLO groups compared to controls (see Supplemental Figure S6, A and B, at http://ajp.amjpathol.org) IL10, on the other hand, was significantly reduced in CLO livers compared to the PBS group, where expression was found to be similar to controls (see Supplemental Figure S6C at http://ajp.amjpathol.org).

\section{Discussion}

During chronic liver injury, compromising liver function, activation of the dormant LPC compartment is observed. Such reaction is believed to be conditioned by changes in the microenvironment enclosing those cells. This microenvironment results from integration of various factors emerging from diseased hepatocytes, ECM, and inflammatory and mesenchymal cells and is by essence subjected to dynamic changes. Here, we demonstrate that ablation of the $\mathrm{KC}$ component of the cellular response to CDE diet, while dramatically per- 

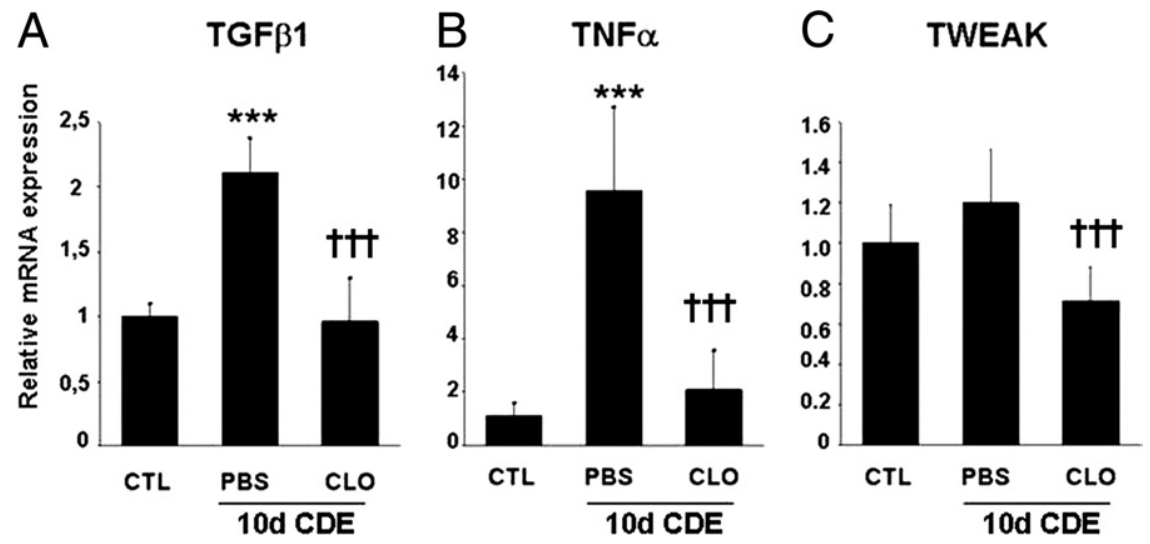

Figure 9. Progenitor cells of Kupffer cell-depleted livers are in a higher state of maturity, with TGF $\beta 1$, TNF $\alpha$, and TWEAK potentially acting as chemoattractants. Hepatic mRNA expression of TGF $\beta 1$ (A), TNF $\alpha(\mathbf{B})$, and TWEAK (C) in control mice and mice receiving the CDE diet for 10 days (10d) with repeated PBS or CLO treatment is shown. Values were normalized to the expression of RPL19 mRNA, regarded as an internal control, and expressed in relation to the mean value in untreated controls, arbitrarily set at 1 . All data are mean ( \pm SD) for $n=5$ /group. ***: $P<0.001$ compared to controls; ${ }^{\text {Ht }} P<0.001$ in CLO-treated compared to PBS-treated CDE counterparts.

turbing myofibroblastic reaction and deposition of ECM, as well as the inflammatory context, does not limit LPC proliferation. By contrast, deletion of $\mathrm{KC}$ and/or a dependent paucity of MF and disruption of the extracellular scaffolding alter the phenotype and invasive character of LPC.

The liposome-mediated macrophage suicide approach is the most effective and best-accepted method of $\mathrm{KC}$ depletion without stimulating the production of proinflammatory cytokines and/or nitric oxide ${ }^{21}$ and without damaging other cell types such as hepatocytes and hepatic stellate cells. ${ }^{24} \mathrm{KC}$ activation is rapid, prominent, and long lasting in CDE livers. This strong requirement for macrophages, imposed by liver damage and cell death, is highlighted by rapid repopulation observed after a single clodronate injection. Indeed, in a normal liver, clodronate wipes out almost all KC for 8 days, and thereafter, progressive repopulation by circulating macrophages/monocytes is initiated, ${ }^{20}$ whereas in CDE livers, 7 days after a single CLO injection, activated macrophages were as numerous as in PBS CDE livers. Prolonged abolition of $\mathrm{KC}$ has been obtained by repeated clodronate injections, treatment otherwise harmless for the animals and for other cell types in the liver. In particular, observations at the 3- and 7-day time points confirmed the absence of clodronate-mediated destruction of HSC and MF (Figure 3E).

The first important observation in this study is that the proliferation of LPC was not affected by the absence of $\mathrm{KC}$. This suggests that KC-released mediators or modulators and associated changes in the inflammatory milieu are not pivotal for early LPC proliferation as it is not compromised despite the reduced expression in $\mathrm{TNF} \alpha$, TWEAK, IL10, suggested to be pro-mitogenic for LPC. ${ }^{12,36,37}$ Our results differ from the study by Olynyk et $\mathrm{al}^{38}$ whereby a role for Kupffer cells was suggested in mediating the ductular reaction in the bile duct-ligated rat model. However, it is generally accepted that bile ductular proliferation after bile duct ligation occurs predominantly by replication of existing ducts rather than through proliferation and differentiation of oval cells into biliary ductules. In addition, the very toxic and liver parenchyma damaging gadolinium chloride used to deplete the Kupffer cells leaves doubts about potentially direct toxicity on the bile duct cells/LPC. Conversely, a promi- nent $\mathrm{KC}$ activation is not sufficient to trigger a response from the liver progenitor cell compartment as observed in CCl4-treated mice (data not shown).

Although likely to be necessary for LPC survival, the amount of activated myofibroblasts and the extent and density of ECM are not limiting factors for early LPC proliferation, because their severe reduction on CLO treatment did not alter the number of LPC. In contrast to our observations, others showed that blocking stellate cells or one of their secreted cytokines, such as CTGF, results in a significant reduction of oval cell proliferation. ${ }^{10,39}$ It remains to be evaluated whether in our model of $\mathrm{KC}$ depletion, MF/ECM response, although reduced, is sufficient to provide enough stimuli for the LPC to continue to expand. Similarly, important questions as to whether LPC growth promotion is triggered only by severe impairment of hepatocytic function, as supported by recently published data, ${ }^{40}$ or might be dependent on other signals, such as the composition of the ECM deposited, are yet to be answered.

The second important observation is that, in absence of (mediators from) KC, the portocentral invasion of LPC is disrupted. Decreased progression of LPC from the portal tract to more central areas of the hepatic lobule is confirmed by decreased distance of irradiation from the portal area where LPC are arising from. Together with alteration in cell morphology (elongated versus rounder) and preferential organization (strings versus aggregates), lack of expression of HGF and different expression of membranous proteins involved in intercellular adhesion (E-cadherin, $\beta$-catenin, and occludin) suggest deficient motility.

Three essential events make parenchymal invasion possible: disruption of intercellular junctions (cell dissociation and reshaping into a motile phenotype), ECM disruption (facilitating cell movement) and dynamic remodeling of adhesive contacts with ECM (supporting cell migration through surface integrin receptors). HGF, found to be less expressed in the CLO group, has the peculiar ability to perform all three functions, as documented by others. ${ }^{28}$ Furthermore, HGF expression has been demonstrated in another model to reach a peak when oval cell proliferation is most prominent and to decline when differentiation occurs. ${ }^{26}$ RANTES, a chemotaxis-related molecule, is expressed by $\alpha$-SMA-posi- 
tive cells ${ }^{41}$ adjacent to the LPC, which in turn express the RANTES receptor (CCR5), indicating their potential responsiveness to RANTES stimulation. ${ }^{9}$ In addition, HSC also express ICAM1, an adhesion factor, on their membrane. ${ }^{42}$ As both RANTES and ICAM1 have been suggested to be implicated in LPC recruitment to the site of injury by mediating LPC adhesion to HSC, ${ }^{9}$ their decreased mRNA expression in CLO CDE livers could, in part, explain the reduced LPC motility. $\beta$-catenin is a member of the adherens junction linking E-cadherin to the cytoskeleton, thereby allowing tight cell-cell adhesion. Low membranous $\beta$-catenin staining in PBS LPC could indicate, although we were not able to demonstrate it, a higher free cytoplasmic pool, able to translocate to the nucleus and bind to transcription factors regulating cell motility, whereas sequestration of $\beta$-catenin at the membrane in CLO LPC would tighten cell-cell junctions and prevent induction of motility. ${ }^{31}$ Occludin, structurally part of the tight junction but mainly implicated in signal transduction and regulation of the actin cytoskeleton, has been shown to be essential for epithelial migration because it is expressed at the leading edges of migrating MDCK (canine kidney epithelial) cells during wound healing and because its knockdown resulted in migration defects. ${ }^{34}$ The distribution of occludin, over the entire cell membrane in PBS LPC and limited to basolateral membrane for CLO LPC, could therefore contribute to the reduced motility of CLO LPC.

Because KC were shown to proceed in advance of invading LPC, reduced cell motility could directly result from the lack of chemoattractant factors released by $\mathrm{KC}$ or other inflammatory cells in which recruitment and activation is perturbed. Candidate factors suspected to contribute to this, either directly or indirectly by remodeling of ECM, are TGF $\beta 1$, TNF $\alpha$, TWEAK, and IL10, as their expression is reduced on CLO treatment. Another and important parameter is the reduction of myofibroblasts and dependent deposition of ECM, which are normally found intermingled with the LPC. A similar reduction in fibrosis was observed after $\mathrm{KC}$ depletion in a mouse model of partial bile duct ligation, of $\mathrm{CCl}_{4}$ - and of methionine and choline-deficient dietinduced liver injury. ${ }^{13,43,44}$ Previous studies in other organs, such as lung and kidney, also showed a role for the macrophages in mediating the fibrotic response. ${ }^{45,46}$ Due to this MF paucity, representative components of the ECM, such as collagens, were unavoidably markedly attenuated, not only in quantity, but also in the thickness of their fibers (Figure 4), and thus possibly, in quality. Accordingly, availability and bio-activation of ECM-retained factors are expected to be modulated. KC could also influence the spatial organization of those pseudofibrotic tracts. Whereas collagen fibers seem to irradiate from the periportal tract and penetrate the parenchyma in the PBS group, this is less observed in the CLO group, where the fibers appear to be more restrained to the portal tract. This observation is compatible with the view that, in the CLO group, the collagen fibers and network of MF are not sufficiently extended or not conditioned to form the structural framework proposed to be needed by the LPC as a migration substratum.

It is described, that, along with parenchymal penetration, LPC mature and progressively gain hepatic lineage determination. ${ }^{3}$ Unfortunately, using this experimental setting, we were not able to evaluate whether KC depletion, and the subsequent defective parenchymal invasion of LPC, also has an impact on their hepatocytic differentiation process. In the $\mathrm{CDE}$ model, only rare $\mathrm{CK} 19^{+}$cells at the parenchymal extremities of LPC arborescence were seen to exhibit a hepatocyte-like morphology suggestive of maturation and hepatocytic commitment, ${ }^{8}$ making it difficult to meaningfully appreciate any modification on CLO treatment. Terminal differentiation might not occur in this CDE model, or if it does, when gaining hepatocytic capacity, maturing cells might become sensitive to the toxicity of the CDE diet and/or become untraceable due to a (rapid and complete) loss of CK19 expression. In this regard, immunostaining using another LPC marker, such as CK7, that may identify cells at different stages of differentiation was not helpful in resolving this issue. Cell tracking experiments and perhaps other models will be required to investigate conditions for functional hepatocytic differentiation. Intriguingly, in the CLO group, some of the aggregated rounder LPC around the portal tract delineate a (pseudo)lumen nicely highlighted by CK19 and occludin staining (Figure 5E, and see Supplemental Figure S4 at http://ajp.amjpathol.org). Those pseudo-ductular-like structures were quasi-absent in the PBS group. Similarly, the expression of $\beta$-catenin and occludin in LPC from CLO-treated animals outlined a biliary-resembling pattern. Together with a decreased expression of CD133 and HGF, supporting lineage commitment, ${ }^{35}$ those observations suggest a biliary differentiation of LPC in the absence of KC.

In conclusion, the present study demonstrates that specific ablation of $\mathrm{KC}$ in the CDE model leads to a defect in associated myofibroblastic reaction and to a migratory deficit and biliary organization of expanding LPC, underlining the importance of cell-cell and/or cellmatrix crosstalk. With this study, we emphasize the importance of investigating cellular components and secreted factors involved in the dynamic changes of the progenitor cell microenvironment to better understand mechanisms governing LPC proliferation and differentiation during chronic liver injury.

\section{Acknowledgments}

The authors are thankful to Profs. Yves Horsmans and Christine Sempoux and Dr. Nicolas Charette for critical review of the manuscript.

The TROMA-III antibody developed by Rolf Kemler was obtained from the Developmental Studies Hybridoma Bank developed under the auspices of the National Institute of Child Health and Human Development and maintained by the University of lowa, Department of Biological Sciences, lowa City, IA. 


\section{References}

1. Akhurst B, Croager EJ, Farley-Roche CA, Ong JK, Dumble ML, Knight B, Yeoh GC: A modified choline-deficient, ethionine-supplemented diet protocol effectively induces oval cells in mouse liver. Hepatology 2001, 34:519-522

2. Theise ND, Saxena R, Portmann BC, Thung SN, Yee H, Chiriboga L, Kumar A, Crawford JM: The canals of Hering and hepatic stem cells in humans. Hepatology 1999, 30:1425-1433

3. Kuwahara R, Kofman AV, Landis CS, Swenson ES, Barendswaard E, Theise ND: The hepatic stem cell niche: identification by label-retaining cell assay. Hepatology 2008, 47:1994-2002

4. Roskams TA, Theise ND, Balabaud C, Bhagat G, Bhathal PS, BioulacSage P, Brunt EM, Crawford JM, Crosby HA, Desmet V, Finegold MJ, Geller SA, Gouw AS, Hytiroglou P, Knisely AS, Kojiro M, Lefkowitch JH, Nakanuma Y, Olynyk JK, Park YN, Portmann B, Saxena R, Scheuer PJ, Strain AJ, Thung SN, Wanless IR, West AB: Nomenclature of the finer branches of the biliary tree: canals, ductules, and ductular reactions in human livers. Hepatology 2004, 39:1739-1745

5. Li L, Xie T: Stem cell niche: structure and function. Annu Rev Cell Dev Biol 2005, 21:605-631

6. Moore KA, Lemischka IR: Stem cells and their niches. Science 2006 , 311:1880-1885

7. Lorenzini S, Bird TG, Boulter L, Bellamy C, Samuel K, Aucott R, Clayton E, Andreone P, Bernardi M, Golding M, Alison MR, Iredale JP, Forbes SJ: Characterisation of a stereotypical cellular and extracellular adult liver progenitor cell niche in rodents and diseased human liver. Gut 2010, 59:645-654

8. Van Hul NK, Abarca-Quinones J, Sempoux C, Horsmans Y, Leclerca IA: Relation between liver progenitor cell expansion and extracellular matrix deposition in a CDE-induced murine model of chronic liver injury. Hepatology 2009, 49:1625-1635

9. Ruddell RG, Knight B, Tirnitz-Parker JE, Akhurst B, Summerville L, Subramaniam VN, Olynyk JK, Ramm GA: Lymphotoxin-beta receptor signaling regulates hepatic stellate cell function and wound healing in a murine model of chronic liver injury. Hepatology 2009, 49:227-239

10. Pintilie DG, Shupe TD, Oh SH, Salganik SV, Darwiche H, Petersen BE: Hepatic stellate cells' involvement in progenitor-mediated liver regeneration. Lab Invest 2010, 90:1199-1208

11. Strick-Marchand H, Masse GX, Weiss MC, Di Santo JP: Lymphocytes support oval cell-dependent liver regeneration. J Immunol 2008, 181: 2764-2771

12. Knight B, Akhurst B, Matthews VB, Ruddell RG, Ramm GA, Abraham LJ, Olynyk JK, Yeoh GC: Attenuated liver progenitor (oval) cell and fibrogenic responses to the choline deficient, ethionine supplemented diet in the BALB/c inbred strain of mice. J Hepatol 2007, 46:134-141

13. Duffield JS, Forbes SJ, Constandinou CM, Clay S, Partolina M, Vuthoori S, Wu S, Lang R, Iredale JP: Selective depletion of macrophages reveals distinct, opposing roles during liver injury and repair. J Clin Invest 2005, 115:56-65

14. Duffield JS: The inflammatory macrophage: a story of Jekyll and Hyde. Clin Sci (Lond) 2003, 104:27-38

15. Imamura M, Ogawa T, Sasaguri Y, Chayama K, Ueno H: Suppression of macrophage infiltration inhibits activation of hepatic stellate cells and liver fibrogenesis in rats. Gastroenterology 2005, 128:138-146

16. Popov Y, Sverdlov DY, Bhaskar KR, Sharma AK, Millonig G, Patsenker E, Krahenbuhl S, Krahenbuhl L, Schuppan D: Macrophage-mediated phagocytosis of apoptotic cholangiocytes contributes to reversal of experimental biliary fibrosis. Am J Physiol Gastrointest Liver Physiol 2010, 298:G323-G334

17. Van Rooijen N, Sanders A: Liposome mediated depletion of macrophages: mechanism of action, preparation of liposomes and applications. J Immunol Methods 1994, 174:83-93

18. Leclercq IA, Lebrun VA, Starkel P. Horsmans YJ: Intrahepatic insulin resistance in a murine model of steatohepatitis: effect of PPARgamma agonist pioglitazone. Lab Invest 2007, 87:56-65

19. Livak KJ, Schmittgen TD: Analysis of relative gene expression data using real-time quantitative PCR and the 2(-Delta Delta C(T)) Method. Methods 2001, 25:402-408

20. Yamamoto $\mathrm{T}$, Naito M, Moriyama $\mathrm{H}$, Umezu $\mathrm{H}$, Matsuo $\mathrm{H}$, Kiwada $\mathrm{H}$, Arakawa M: Repopulation of murine Kupffer cells after intravenous ad- ministration of liposome-encapsulated dichloromethylene diphosphonate. Am J Pathol 1996, 149:1271-1286

21. van Rooijen N, Sanders A: Elimination, blocking, and activation of macrophages: three of a kind? J Leukoc Biol 1997, 62:702-709

22. Lanthier N, Molendi-Coste O, Horsmans Y, van Rooijen N, Cani PD, Leclercq IA: Kupffer cell activation is a causal factor for hepatic insulin resistance, Am J Physiol Gastrointest Liver Physiol 2010, 298 : G107-G116

23. Seki E, De Minicis S, Osterreicher CH, Kluwe J, Osawa Y, Brenner DA, Schwabe RF: TLR4 enhances TGF-beta signaling and hepatic fibrosis. Nat Med 2007, 13:1324-1332

24. Inokuchi S, Aoyama T, Miura K, Osterreicher CH, Kodama Y, Miyai K, Akira S, Brenner DA, Seki E: Disruption of TAK1 in hepatocytes causes hepatic injury, inflammation, fibrosis, and carcinogenesis, Proc Natl Acad Sci U S A 2010, 107:844-849

25. Matsuo A, Yoshida T, Yasukawa T, Miki R, Kume K, Kume S: Epiplakin1 is expressed in the cholangiocyte lineage cells in normal liver and adult progenitor cells in injured liver, Gene Expr Patterns 2011, 11:255-262

26. Hu Z, Evarts RP, Fujio K, Marsden ER, Thorgeirsson SS: Expression of hepatocyte growth factor and c-met genes during hepatic differentiation and liver development in the rat. Am J Pathol 1993, 142:18231830

27. Stoker M, Perryman M: An epithelial scatter factor released by embryo fibroblasts. J Cell Sci 1985, 77:209-223

28. Trusolino L, Cavassa S, Angelini P, Ando M, Bertotti A, Comoglio PM, Boccaccio C: HGF/scatter factor selectively promotes cell invasion by increasing integrin avidity. FASEB J 2000, 14:1629-1640

29. Takeichi M: Cadherins in cancer: implications for invasion and metastasis. Curr Opin Cell Biol 1993, 5:806-811

30. Birchmeier W, Hulsken J, Behrens J: Adherens junction proteins in tumour progression. Cancer Surv 1995, 24:129-140

31. Muller T, Bain G, Wang X, Papkoff J: Regulation of epithelial cell migration and tumor formation by beta-catenin signaling. Exp Cell Res 2002, 280:119-133

32. Yovchev MI, Grozdanov PN, Joseph B, Gupta S, Dabeva MD: Novel hepatic progenitor cell surface markers in the adult rat liver. Hepatology 2007, 45:139-149

33. Ueberham E, Aigner T, Ueberham U, Gebhardt R: E-cadherin as a reliable cell surface marker for the identification of liver specific stem cells. J Mol Histol 2007, 38:359-368

34. Du D, Xu F, Yu L, Zhang C, Lu X, Yuan H, Huang Q, Zhang F, Bao H, Jia L, Wu X, Zhu X, Zhang X, Zhang Z, Chen Z: The tight junction protein, occludin, regulates the directional migration of epithelial cells. Dev Cell 2010, 18:52-63

35. Spee B, Carpino G, Schotanus BA, Katoonizadeh A, Vander Borght S, Gaudio E, Roskams T: Characterisation of the liver progenitor cell niche in liver diseases: potential involvement of Wnt and Notch signalling. Gut 2010, 59:247-257

36. Jakubowski A, Ambrose C, Parr M, Lincecum JM, Wang MZ, Zheng TS, Browning B, Michaelson JS, Baetscher M, Wang B, Bissell DM, Burkly LC: TWEAK induces liver progenitor cell proliferation. J Clin Invest 2005, 115:2330-2340

37. Viebahn CS, Benseler V, Holz LE, Elsegood CL, Vo M, Bertolino P, Ganss R, Yeoh GC: Invading macrophages play a major role in the liver progenitor cell response to chronic liver injury. J Hepatol 2010, 53:500-507

38. Olynyk JK, Yeoh GC, Ramm GA, Clarke SL, Hall PM, Britton RS, Bacon BR, Tracy TF: Gadolinium chloride suppresses hepatic oval cell proliferation in rats with biliary obstruction. Am J Pathol 1998, 152:347-352

39. Pi L, Oh SH, Shupe T, Petersen BE: Role of connective tissue growth factor in oval cell response during liver regeneration after 2-AAF/PHX in rats. Gastroenterology 2005, 128:2077-2088

40. Jung Y, Witek RP, Syn WK, Choi SS, Omenetti A, Premont R, Guy CD, Diehl AM: Signals from dying hepatocytes trigger growth of liver progenitors. Gut 2010, 59:655-665

41. Schwabe RF, Bataller R, Brenner DA: Human hepatic stellate cells express CCR5 and RANTES to induce proliferation and migration. Am J Physiol Gastrointest Liver Physiol 2003, 285:G949-G958

42. Hellerbrand, Wang SC, Tsukamoto H, Brenner DA, Rippe RA: Expression of intracellular adhesion molecule 1 by activated hepatic stellate cells. Hepatology 1996, 24:670-676 
43. Osawa Y, Seki E, Adachi M, Suetsugu A, Ito H, Moriwaki H, Seishima M, Nagaki M: Role of acid sphingomyelinase of Kupffer cells in cholestatic liver injury in mice. Hepatology 2010, 51:237-245

44. Rivera CA, Adegboyega P, van Rooijen N, Tagalicud A, Allman M, Wallace M: Toll-like receptor-4 signaling and Kupffer cells play pivotal roles in the pathogenesis of non-alcoholic steatohepatitis. J Hepatol 2007, 47:571-579
45. Westerhuis $R$, van Straaten SC, van Dixhoorn MG, van Rooijen N, Verhagen NA, Dijkstra CD, de Heer E, Daha MR: Distinctive roles of neutrophils and monocytes in anti-thy-1 nephritis. Am J Pathol 2000, 156:303-310

46. Zhang-Hoover J, Sutton A, van Rooijen N, Stein-Streilein J: A critical role for alveolar macrophages in elicitation of pulmonary immune fibrosis. Immunology 2000, 101:501-511 